\title{
Induction of Hyperinsulinemia and Hyperglycemia in Dogs by Administration of Diabetogenic Bovine Pituitary Peptide
}

\author{
By Lawrence H. Louis, J. W. Conn and Mary M. Appelt
}

A peptide exhibiting diabetogenic and anti-insulin properties isolated from bovine adenohypophysis was administered subcutaneously in single doses to four dogs for 2 to 3 consecutive days. Ten hours after each injection, the animals were given an oral glucose load and a series of blood samples were obtained for glucose and insulin determinations. In one dog, the procedure was repeated 13 days after the first one. In another ani- mal, the same procedure was carried out three times. Glucose tolerance was clearly impaired and serum insulin rose excessively in three of the four animals. In the fourth animal the response was observed but only after the third injection. Thus, insulin resistance appears to be a major mechanism by which this peptide induces loss of carbohydrate tolerance. (Metabolism 20: No. 3, March, 326-330, 1971)

$\mathbf{P}$ REVIOUS PUBLICATIONS from this laboratory have demonstrated the presence of a diabetogenic peptide in the urine of patients with lipoatrophic diabetes $^{1}$ and of proteinuric diabetic patients without lipoatrophy. ${ }^{2}$ The substance is not present in the urine of proteinuric patients without diabetes, diabetics without proteinuria and healthy people. ${ }^{2} \mathrm{~A}$ similar diabetogenic peptide has also been isolated from the adenohypophyses of beef, ${ }^{3}$ hog and sheep. ${ }^{4}$ The peptide from all of these sources produces hyperglycemia and induces antagonism to the action of exogenous insulin when administered to dogs or man. The mechanism by which the peptide acts has not been known but it was inferred from the above mentioned findings that resistance to endogenous insulin was probably a major factor.

In an attempt to study this possibility we have administered subcutaneously in dogs the peptide obtained from bovine adenohypophysis and have measured the serum insulin and blood glucose responses to glucose administered by gastric tube. The results indicate that resistance to endogenous insulin is a major factor in the mechanism by which the peptide induces hyperglycemia.

From the Department of Internal Medicine, Division of Endocrinology and Metabolism and the Metabolism Research Unit, University of Michigan Medical School, Ann Arbor, Mich.

Received for publication August 11, 1970.

Supported by USPHS Grant AM-06665, National Institutes of Arthritis and Metabolic Diseases.

LAWReNCE H. Louis, Sc.D.: Professor of Biological Chemistry, Department of Internal Medicine, University of Michigan Medical School, Ann Arbor, Mich. Jerome W. ConN, M.D.: L. H. Newburgh University Professor of Internal Medicine; Head, Division of Endocrinology and Metabolism; Director, Metabolism Research Unit, University of Michigan Medical School, Ann Arbor, Mich. Mary M. APPELT, B.S.: Third Year Medical Student, University of Michigan Medical School, Ann Arbor, Mich. 
Table 1

Dog Kơ 14. $1 \mathrm{Kg}$ Body Wt.

Effect of Bovine P' Upon Glucose Tolerance and Serum Insulin Level

\begin{tabular}{|c|c|c|c|c|c|c|c|}
\hline & $F$ & $1 / 2$ & 1 & $1 / 1 / 2$ & 2 & $2 \mathrm{l} / 2$ & 3 \\
\hline \multicolumn{8}{|c|}{ Glucose $\mathrm{mg} \%$} \\
\hline Control tlt & 83 & 107 & 89 & 80 & 81 & 80 & 85 \\
\hline Control 121 & 84 & 126 & 78 & $8 !$ & 88 & 79 & 78 \\
\hline $\begin{array}{l}10 \mathrm{hrs} \text {. after lst inj. } \\
3 \mathrm{mg} / \mathrm{kg}\end{array}$ & 87 & 201 & 165 & 101 & 89 & 92 & 72 \\
\hline $\begin{array}{l}10 \mathrm{hrs}, \text { after } 2 \mathrm{nd} \text { inj. } \\
4 \mathrm{mg} / \mathrm{kg}\end{array}$ & 75 & 178 & 265 & $: 50$ & 118 & 84 & 84 \\
\hline $\begin{array}{l}10 \mathrm{hrs.} \text { after } 3 \mathrm{rd} \mathrm{inj.} \\
5 \mathrm{mg} / \mathrm{kg}\end{array}$ & 102 & 215 & 226 & 145 & .15 & 106 & 106 \\
\hline $34 \mathrm{hrs}$. after $3 \mathrm{rd}$ in $\mathrm{j}$. & 99 & 138 & 124 & 97 & 96 & 93 & 92 \\
\hline \multicolumn{8}{|c|}{ Insulin uvim! } \\
\hline Control (1) & 5 & 6 & 4 & 4 & 6 & 15 & 9 \\
\hline Control $\{2\}$ & 12 & 73 & 32 & 22 & 12 & 10 & 11 \\
\hline $\begin{array}{l}\text { lo hrs. after lst inj. } \\
3 \mathrm{mg} / \mathrm{kg}\end{array}$ & 18 & 112 & 47 & 48 & 15 & 15 & 34 \\
\hline $\begin{array}{l}10 \mathrm{hrs} \text {. after } 2 \text { nd inj. } \\
4 \mathrm{mg} / \mathrm{kg}\end{array}$ & 69 & 173 & 180 & 94 & 68 & 68 & 49 \\
\hline $\begin{array}{l}10 \mathrm{hrs} \text {. diter } 3 \mathrm{rll} \mathrm{lll} . \\
5 \mathrm{mg} / \mathrm{kg}\end{array}$ & 45 & 229 & 126 & 78 & 43 & 43 & 38 \\
\hline $34 \mathrm{hrs}$. after $3 \mathrm{nd}$ inj. & 38 & 164 & 28 & 26 & 26 & 26 & 20 \\
\hline
\end{tabular}

Table 2

Dog $0911.3 \mathrm{Kg}$ Body Wt.

\begin{tabular}{|c|c|c|c|c|c|c|c|}
\hline & $\mathrm{F}$ & $1 / 2$ & 1 & $11 / 2$ & 2 & $2 \mathrm{ll}$ & 3 \\
\hline \multicolumn{8}{|c|}{ Glucose mg } \\
\hline Control +11 & 83 & Jll & 99 & 78 & 75 & 79 & 80 \\
\hline Control !2 & 78 & 110 & 108 & 85 & 72 & 73 & 19 \\
\hline $\begin{array}{l}10 \mathrm{hrs} \text {. after lst inj. } \\
3 \mathrm{mg} / \mathrm{kg}\end{array}$ & 82 & 107 & 132 & $\mathrm{i} 06$ & 82 & 76 & 79 \\
\hline $\begin{array}{l}10 \mathrm{hrs} \text { after } 7 \mathrm{nt} \text { inf } \\
4 \mathrm{mg} / \mathrm{kg}\end{array}$ & 74 & 115 & 120 & 118 & 81 & 01 & 13 \\
\hline $\begin{array}{l}10 \mathrm{hrs} \text {. after } 3 \mathrm{rd} \text { inj. } \\
5 \mathrm{mg} / \mathrm{kg}\end{array}$ & 92 & .68 & 167 & 182 & 112 & 85 & 34 \\
\hline $34 \mathrm{hrs}$, alter 3rd inf. & 90 & 119 & 100 & 119 & 94 & 79 & 83 \\
\hline \multicolumn{8}{|c|}{ Insulin uU/mI } \\
\hline Control tit & 10 & 49 & 34 & 6 & 9 & 7 & 4 \\
\hline Control (2) & 10 & 59 & 88 & 21 & 14 & 14 & 21 \\
\hline $\begin{array}{l}10 \mathrm{hrss} \text {. after lst inj. } \\
3 \mathrm{mg} / \mathrm{kg}\end{array}$ & 18 & 35 & 57 & 38 & 17 & 16 & 17 \\
\hline $\begin{array}{l}10 \mathrm{hrs} \text {. after 2nd inj. } \\
4 \mathrm{mg} / \mathrm{kg}\end{array}$ & 19 & 53 & 71 & 66 & 41 & 19 & 24 \\
\hline $\begin{array}{l}20 \mathrm{nrs} \text {. atter } 3 \mathrm{rd} \text { inj. } \\
5 \mathrm{mg} / \mathrm{kg}\end{array}$ & 24 & 138 & 107 & 132 & 69 & 30 & 2. \\
\hline $34 \mathrm{hrs}$. after 3rd inj. & 48 & $! 16$ & 104 & 84 & 28 & 16 & 32 \\
\hline
\end{tabular}

\section{Materials and Methods}

Isolation of a diabetogenic peptide, designated as PI, from bovine adenohypophysis has been described. ${ }^{3}$ The isolated substance is prepared for injection by solution in dilute hydrochloric acid $(0.05-0.1 \mathrm{~N})$ and neutralization with $0.05 \mathrm{~N} \mathrm{NaOH}$ to $\mathrm{pH}$ 7.0-7.4. The solution has been administered subcutaneously as a single dose.

Four trained dogs, one female and three males, were studied. They were maintained between tests on a diet of Friskies Mix dog food and one can of Pard. For 3 days prior to and throughout the testing periods, the daily diet consisted of $454 \mathrm{Gm}$. of Pard, $100 \mathrm{Gm}$. Friskies and $60 \mathrm{Gm}$. of sucrose. No food was eaten after 10:00 p.m. Oral (gastric intubation) glucose tolerance tests were begun between 8:00 and 9:00 a.m. The experimental procedure consisted of two control glucose tolerance tests done on days 1 and 2; a subcutaneous injection of the peptide 10 hours before the third glucose tolerance test which was done on day 3; administration of a single dose of the peptide daily for two more days with glucose tolerance tests being done on days 4 and 5; and a final glucose tolerance test carried out 34 hours after the last injection of peptide (day 6). This series of tests is designated as "Test Period I." Postpeptide glucose tolerance tests were carried out 13 and 14 days after the last administration of peptide. Following an interval of at least 13 days, a second similar testing period, "Test Period II," was begun. In one dog, "Test Period III" was also performed. Blood glucose was determined by the Somogyi-Nelson Procedure.5 Serum insulin was measured by the radioimmunoassay technique of Yalow and Berson. ${ }^{6}$ Campbell et al. had shown that values obtained by the immunoassay procedure were actually representative of insulin concentrations in dog serum. ${ }^{7}$

\section{RESUlTS}

Blood glucose and serum insulin values for Dog $\mathrm{K}$ are presented in Table 1. Both insulin and glucose levels are greatly elevated by injection of this compound. Thirteen and fourteen days after peptide administration, the values had returned to normal. Dog $\mathrm{O}$, Table 2, showed no significant change until the third day of peptide injection. There then occurred a mild rise of serum insulin and a marked impairment of glucose tolerance.

The results of Dog $T$ are depicted in Tables 3 and 4 . It is apparent that glucose tolerance was greatly impaired and that serum insulin levels rose sharply. 
Table 3

Dog Tor $33 \mathrm{Kg}$ Body Wt.

(Test Period I)

Effect of Bovine PI Upon Glucose Tolerance and Serum insulin Leve

\begin{tabular}{|c|c|c|c|c|c|c|c|}
\hline & $\mathrm{F}$ & $1 / 2$ & l & 1112 & 2 & 212 & 3 \\
\hline \multicolumn{8}{|c|}{ Glucose mg\% } \\
\hline $\begin{array}{l}\text { Control (ll } \\
\text { ibovine alsumin } 4 \mathrm{mg} / \mathrm{kg} \text { ) }\end{array}$ & 75 & - & 72 & 61 & 64 & 67 & 67 \\
\hline Control $\{2 \mid$ & 93 & [3] & 113 & 78 & 76 & 81 & 84 \\
\hline $\begin{array}{l}10 \mathrm{hrs} \text {. alter lst inj. } \\
4 \mathrm{mg} / \mathrm{kg}\end{array}$ & 67 & $13 i$ & 220 & 283 & 143 & 83 & $6 \mathfrak{9}$ \\
\hline $\begin{array}{l}10 \mathrm{hrs} \text {. after } 2 \text { nd inj. } \\
5 \mathrm{mg} / \mathrm{kg}\end{array}$ & 89 & 175 & 236 & 230 & 136 & 99 & 93 \\
\hline $\begin{array}{l}10 \mathrm{hrs} \text {, atter } 3 \mathrm{rd} \mathrm{inj} \text {. } \\
6 \mathrm{mg} / \mathrm{kg}\end{array}$ & 77 & 132 & 107 & 125 & 132 & $11 \% k$ & $n$ \\
\hline $34 \mathrm{hrs}$. after $3 \mathrm{rd}$ inj. & 72 & 165 & 92 & 67 & 71 & 65 & 80 \\
\hline \multicolumn{8}{|c|}{ Insulin uU/mI } \\
\hline Control 1$\}$ & 8 & - & 13 & 9 & 6 & 8. & 9 \\
\hline Control 121 & 7 & 98 & 73 & 10 & 2 & 0 & 4 \\
\hline $\begin{array}{l}10 \mathrm{hrs} \text {, after lst inj. } \\
4 \mathrm{mg} / \mathrm{kg}\end{array}$ & 30 & 72 & 94 & 109 & 107 & 14 & 13 \\
\hline $\begin{array}{l}10 \mathrm{hrs} \text {. after } 2 \text { nd inj. } \\
5 \mathrm{mg} / \mathrm{kg}\end{array}$ & 43 & 175 & 154 & 208 & 89 & 27 & 54 \\
\hline $\begin{array}{l}10 \mathrm{hrs} \text {. after } 3 \mathrm{rd} \text { inj. } \\
6 \mathrm{mg} / \mathrm{kg}\end{array}$ & 26 & 263 & 230 & 147 & 183 & 32 & 19 \\
\hline $34 \mathrm{hrs}$. after 3 rd inj. & 14 & 137 & 34 & 27 & 27 & 44 & 36 \\
\hline
\end{tabular}

Table 4

Dog Id $13 \mathrm{~kg}$ Body Wi.

(Test Perind 11

Effect of Bovine PI Upan Glucose Tolerance and Serium Insulin Leve

\begin{tabular}{|c|c|c|c|c|c|c|c|}
\hline & IF & $1 / 2$ & 1 & 1112 & 2 & $2 \mathrm{li2}$ & 3 \\
\hline \multicolumn{8}{|c|}{ Glucose mg\% } \\
\hline $\begin{array}{l}\text { Control (l) } \\
\text { tboving albumin } 4 \mathrm{mg} / \mathrm{kg}\end{array}$ & 66 & 90 & 94 & 96 & 66 & 54 & 59 \\
\hline Control (2) & 71 & 90 & 103 & 68 & 61 & 60 & 64 \\
\hline $\begin{array}{l}10 \mathrm{hrs} \text {, diter tst inj. } \\
4 \mathrm{mg} / \mathrm{kg}\end{array}$ & 90 & 156 & 163 & 150 & 88 & 90 & 92 \\
\hline $\begin{array}{l}10 \mathrm{hrs} \text {. dlter } 2 \mathrm{nd} \text { inj. } \\
5 \mathrm{mg} / \mathrm{kg}\end{array}$ & 100 & 175 & 203 & 191 & 111 & 86 & 76 \\
\hline $\begin{array}{l}10 \mathrm{hrs} \text {. atter } 3 \text { rd inj. } \\
6 \mathrm{mg} / \mathrm{kg}\end{array}$ & 99 & 178 & 独 & $23 \pi$ & 136 & 109 & 86 \\
\hline 34 hrs. atter $3 r d$ inj. & 68 & 124 & 165 & 143 & 84 & 70 & 75 \\
\hline \multicolumn{8}{|c|}{ Insulin Luimi } \\
\hline Control (1) & 9 & 96 & 108 & 116 & 15 & 8 & 8 \\
\hline Contro: (2) & 14 & 116 & 123 & 25 & 10 & 14 & 7 \\
\hline $\begin{array}{l}10 \mathrm{hrs} \text {. dfter lst inj. } \\
4 \mathrm{mg} / \mathrm{kg}\end{array}$ & 169 & 4.4 & 302 & 378 & 68 & 113 & 88 \\
\hline $\begin{array}{l}10 \mathrm{hrs} \text {. after and inj. } \\
5 \mathrm{mg} / \mathrm{kg}\end{array}$ & 214 & 454 & 544 & 686 & 146 & 235 & 197 \\
\hline $\begin{array}{l}\text { lo hrs. after 3rd inj. } \\
6 \mathrm{mg} / \mathrm{kg}\end{array}$ & 248 & 550 & 688 & 596 & 676 & 606 & 316 \\
\hline 34 hrs. aster 3rd inj. & 87 & 249 & 254 & 354 & 66 & 22 & 30 \\
\hline
\end{tabular}

In both test periods, there occurred an important risc of the fasting serum insulin level as well. By 13 and 14 days after the last injection of peptide, blood glucose and insulin levels had returned to normal. The results on Dog $L$ are shown in Tables 5 and 6. The responses of this animal are very similar to those of Dog $\mathrm{T}$, except that they are more intense. Again, the fasting serum insulin value was greatly elevated. However, in "Test Period III," glucose tolerance was normal and serum insulin was only mildly elevated. The reason for this finding is unclear at present. Perhaps a sufficient antibody titer had been produced to overcome the activity of the administered material. Studies in this area are in

Table 5

$\operatorname{Dog} 1015.9 \mathrm{Kg}$ Body Wt.

iTest Period I:

Elfect of Bovine PI Upon Glucose Tolerance ano Serum Insulin Level

\begin{tabular}{|c|c|c|c|c|c|c|c|}
\hline & $\mathrm{F}$ & $1 / 2$ & 1 & $11 / 2$ & 2 & 21,2 & 3 \\
\hline \multicolumn{8}{|c|}{ Giucose $m g \%$} \\
\hline $\begin{array}{l}\text { Control (1) } \\
\text { Ibovine abumin } 4 \mathrm{mg} / \mathrm{kg})\end{array}$ & 77 & 100 & 100 & 202 & 71 & 81 & 79 \\
\hline Control (2) & 76 & 147 & 127 & 84 & 74 & 79 & 80 \\
\hline $\begin{array}{l}\text { lohrs. after lst inj. } \\
4 \mathrm{mg} / \mathrm{kg}\end{array}$ & 70 & 166 & 192 & 212 & 134 & 93 & 9] \\
\hline $\begin{array}{l}10 \mathrm{hrs} \text {, alter 2nd inj. } \\
4 \mathrm{mg} \text { ikg }\end{array}$ & 93 & 154 & 254 & 288 & 228 & 159 & 341 \\
\hline $34 \mathrm{hrs}$. after 2 nd inj. & 78 & 145 & 205 & 229 & 161 & 121 & 100 \\
\hline $58 \mathrm{hrs}$. after 2nd inj. & 71 & 139 & 178 & 189 & 115 & 65 & 72 \\
\hline \multicolumn{8}{|c|}{ Insulin } \\
\hline Control (1) & 32 & 130 & 104 & 136 & 9 & 9 & 11 \\
\hline Control (2) & 16 & 181 & 218 & 98 & 9 & 25 & 10 \\
\hline $\begin{array}{l}10 \mathrm{hrs} \text {. after ist inj. } \\
4 \mathrm{nty} / \mathrm{ky}\end{array}$ & 42 & 288 & 310 & 352 & 259 & 100 & 43 \\
\hline $\begin{array}{l}10 \mathrm{hrs} \text {. alter } 2 \text { nd inj. } \\
4 \mathrm{mg} / \mathrm{kg}\end{array}$ & 159 & 430 & 381 & 429 & 449 & 334 & 284 \\
\hline $34 \mathrm{hrs}$. after 2nd inj. & 58 & 342 & 376 & 392 & 407 & 398 & $10:$ \\
\hline $58 \mathrm{hrs}$. after 2nd inj. & 46 & 354 & 368 & 352 & 176 & 44 & 32 \\
\hline
\end{tabular}

Table 6

nog 1 o $15.9 \mathrm{~kg}$ Rinly Wt.

(Test Period 11 ?

Effect of Bovine PI Upon Glucose Tolerance and Serum Insulin tevet

\begin{tabular}{|c|c|c|c|c|c|c|c|}
\hline & $F$ & $1 / 2$ & 1 & $11 / 2$ & 2 & $21 / 2$ & 3 \\
\hline \multicolumn{8}{|c|}{ olucose mg\% } \\
\hline $\begin{array}{l}\text { Control (1) } \\
\text { (bovine albumin } 4 \mathrm{mg} / \mathrm{kg})\end{array}$ & 79 & 119 & 101 & 89 & 78 & $n$ & 77 \\
\hline Control (2) & 76 & .28 & 106 & 102 & 64 & 71 & 70 \\
\hline $\begin{array}{l}10 \mathrm{hrs} \text {. alter lst inj. } \\
4 \mathrm{mg} / \mathrm{kg}\end{array}$ & $n$ & 107 & .07 & 109 & 74 & 73 & 74 \\
\hline $\begin{array}{l}10 \mathrm{hrs} \text { after 2nd inj. } \\
5 \mathrm{mg} / \mathrm{kg}\end{array}$ & $9 !$ & 137 & 171 & 189 & 155 & 95 & 87 \\
\hline $\begin{array}{l}0 \mathrm{hrs} \text {. alter } 3 \mathrm{rd} \text { inj. } \\
6 \mathrm{mg} / \mathrm{kg}\end{array}$ & 109 & 169 & 255 & 291 & 255 & 211 & 173 \\
\hline $34 \mathrm{hrs}$. after 3 rd inj. & 103 & 155 & 306 & 274 & 237 & 170 & 142 \\
\hline \multicolumn{8}{|c|}{ insulin $u l|l / m|$} \\
\hline Control (l) & 23 & 135 & 143 & 72 & 9 & 9 & 13 \\
\hline Control (2) & 19 & 130 & 160 & 81 & 10 & 6 & 17 \\
\hline $\begin{array}{l}10 \mathrm{hrs} \text {. after lst inj. } \\
4 \mathrm{my} / \mathrm{kg}\end{array}$ & 41 & 215 & 257 & 142 & 19 & 8 & 7 \\
\hline $\begin{array}{l}10 \mathrm{hrs} \text {. after } 2 \mathrm{nd} \mathrm{inj} \text {. } \\
5 \mathrm{mg} / \mathrm{kg}\end{array}$ & 57 & 347 & 574 & 303 & 245 & 45 & 56 \\
\hline $\begin{array}{l}10 \mathrm{hrs} \text {, after } 3 \mathrm{rd} \text { inj. } \\
6 \mathrm{mg} / \mathrm{kg}\end{array}$ & 224 & 514 & 651 & 521 & 566 & 508 & 552 \\
\hline $34 \mathrm{hrs}$. after $3 r \mathrm{r}$ inj. & 125 & 370 & 555 & 532 & 472 & 386 & 266 \\
\hline
\end{tabular}


progress. It should be noted that for Dogs $\mathrm{T}$ and $\mathrm{L}$, the doses of peptide administered were somewhat larger than those given to Dogs $\mathrm{K}$ and $\mathrm{O}$.

\section{COMMENT}

The present study demonstrates that administration of our bovine diabetogenic peptide to dogs results in hyperinsulinemia together with impairment of glucose tolerance. It has been shown that bovine growth hormone is also capable of inducing simultaneously hyperinsulinemia and hyperglycemia in dogs.$^{7-9}$ Because growth hormone and our peptide have similar diabetogenic properties, we have compared the growth promoting activity of these two peptides by means of the tibia test of Greenspan et al. ${ }^{10}$ It was found that our diabetogenic peptide has no significant growth promoting activity. ${ }^{11}$ It has been shown that bovine growth hormone can be degraded by trypsin or chymotrypsin after which it may be capable of inducing carbohydrate intolerance in man. ${ }^{12,13}$ The possibility that our diabetogenic polypeptide is a part of the growth hormone molecule cannot be excluded completely but it is an unlikely one, since no diabetogenic peptide at $\mathrm{pH} 4.1$ was obtained when bovine growth hormone (NIH-GH-B8) itself was subjected to our procedure of isolation. Previous results from this laboratory have shown that our substance has no ACTH effects in man. ${ }^{3}$ No significant prolactin activity as measured by the Reece-Turner intradermal pigeon crop technique could be demonstrated. ${ }^{*}$ Thus, it seems reasonable to conclude that our substance is different from other known pituitary hormones.

The possibility exists that this substance may induce beta cell release of abnormal quantities of an immunodetectable moeity of insulin with low biological activity, such as proinsulin. We have not yet made these measurements but such a mechanism could not explain the entire phenomenon, since we have already found $^{1-4}$ decreased sensitivity to intravenously administered exogenous insulin in dogs and men treated with this compound.

It is premature to speculate upon the possible physiological significance of this substance but it is important that we have recently isolated it from pituitary glands of man. ${ }^{15}$

\section{ACKNOWLEDGMENT}

The authors thank Dr. John C. Floyd for supervision of the measurement of serum insulin and Mrs. Sendy Su for her help in various aspects of this work.

\section{REFERFNCES}

1. Louis, L. H., Conn, J. W., and Minick. M. C.: Lipoatrophic diabetes: Isolation and characterization of an insulin antagonist from urine. Metabolism, 12:867-886, 1963.

2. Louis, L. H. and Conn, J. W.: A urinary diabetogenic peptide from proteinuric diabetic patients. Metabolism, 18:556-563, 1969.

3. Louis, L. H., Conn, J. W., and Minick, M. C.: A diabetogenic polypeptide from bovine adenohypophysis similar to that excreted in lipoatrophic diabetes. Metabolism, 15:308-324, 1966.
4. Louis, L. H., and Conn, J. W.: A diabetogenic polypeptide from hog and sheep adenohypophysis similar to that found in lipoatrophic diabetes. Metabolism, 17: 475-484, 1968.

5. Somogyi, M.: Notes on sugar determination. J. Biol. Chem., 195:19, 1952.

6. Yalow, R. S. and Berson, S. A.: Immunoassay of endogenous plasma insulin in man. J. Clin. Invest., 39:1157-1175, 1960.

7. Campbell, J. and Rastogi, K. S.: Growth hormone-induced diabetes and high 
level of serum insulin in dogs. Diabetes, 15 : 30-43, 1966.

8. Randle, P. J., and Young, F. G.: The influence of pituitary growth hormone on plasma insulin activity. J. Endocrinol., $13: 335,1956$.

9. Campbell, J. and Rastogi, K. S.: Augmented insulin secretion due to growth hormone. Diabetes, 15:749-758, 1966.

10. Greenspan, F. S., Li, C. H., Simpson, M. E., and Evans, H. M.: Bioassay of hypophyseal growth hormone: The tibia test. Endocrinology, 45:455-563, 1949.

11. Tutwiler, G. F. and Louis, L. H.: Glycostatic effect of a diabetogenic nongrowth promoting pituitary polypeptide. Int. J. Biochem.
12. Sonenberg, M., Free, C. A., Dellacha, J. M., Bonadonna, G., Haymowitz, A., and Nadler, A. C.: The metabolic effects in man of bovine growth hormone digested with trypsin. J. Clin. Invest., 44:1099, 1965.

13. Sonenberg, M., Free, C. A., Dellacha, J. M., Bonadonna, G., Haymowitz, A., and Nadler, A. C.: The metabolic effects in man of bovine growth hormone digested with trypsin. Metabolism, 14:1189-1213, 1965.

14. Sonenberg, M., Dellacha, J. W., Free, C. A., and Nadler, A. C.: Growth hormone activity in man of chymotryptic digest of bovine growth hormone. J. Endocr. 44:255265, 1969.

15. Louis, L. H.: Unpublished data. 